\title{
COMPARISON OF GENETIC AND MERISTIC CHARACTERS \\ OF YELLOWSTONE NATIONAL PARK, MONTANA \\ AND ARCTIC GRAYLING POPULATIONS
}

\author{
E. R. Vyse \\ W. R. Gould $\%$ \\ Biology Department \\ Montana State University
}

\section{Objectives}

Yellowstone National Park initiated a grayling restoration program in 1971 , to reestablish grayling in small headwater systems of the Missouri River in YNP. Comparative genetic analysis of arctic and Montana grayling was initiated to identify pure populations of Montana grayling as a source of eggs or fry. The initial stocking attempt utilizing grayling derived from a lacustrine population (Grebe Lake in YNP) was unsuccessful because the grayling failed to hold stream position and drifted downstream into the Missouri River. A second stocking attempt with fish from the Bighole River in Montana was apparently successful. A comparative genetic analysis of lacustrine and adfluvial populations was started in 1977.

Previous genetic studies (Lynch and Vyse 1979) have shown that a genetic difference exists between the two arctic grayling and the two Montana grayling populations sampled, while no genetic differences were found in the genetic screening of thirty presumptive loci in a comparison of Grebe Lake, YNP and Bighole River populations (Progress Report. Vyse 1978).

In 1978-79 we proposed to extend our genetic comparisons to other arctic grayling populations and to analyze additional presumptive loci in our comparisons of Bighole River and locustrine grayling from Grebe Lake, YNP. In addition, Dr, W. R. Gould agreed to compare some meristic characters in these and other populations.

\section{Methods}

Grayling populations were sampled by electrofishing or angling (Table 1). Tissue samples were taken immediately and frozen on dry ice. Blood samples were kept on ice until cells and serum could be separated by centrifugation and then stored at $-50 \mathrm{C}$. Yukon territory and Mackenzie River samples have been kindly provided by Dr. J. Clayton, Freshwater

$* D r$. Gould's report on meristic characters follows the genetic report. 
Institute, Winnipeg, Manitoba, Canada. We have not had an opportunity to analyze any of these arctic grayling samples. Samples were ground in an equivalent volume of $0.01 \mathrm{M} \mathrm{Tris-HCl}$ buffer $\mathrm{pH} 6.8$ containing $0.001 \mathrm{M}$ EDTA and $5 \times 10^{-5} \mathrm{M}$ NADP. Starch gel electrophores is was performed as described by Lynch and Vyse (1979) (adapted from Allendorf et al. 1974, 1977; Selander et al. 1971, and Harris and Hopkinson 1976).

The initial electrophoretic screening of all enzymes was done utilizing only two buffer systems, 1. Electrode: $0.30 \mathrm{M}$ borate $\mathrm{pH}, 8.2$. Gel: 0.076 M tris $-0.005 \mathrm{M}$ citric acid pH 8.7. Potential: $250 \mathrm{v}$ for $3 \mathrm{hr}$. or 2 . Electrode: $0.04 \mathrm{M}$ citric acid, $\mathrm{pH} 6.1$. Gel: $0.002 \mathrm{M}$ citric acid, pH 6,1. Both buffers are $\mathrm{pH}$ adjusted with $\mathrm{N}$-(3-Aminopropy 1 )-morpholine. Potential 200 volts for $3 \mathrm{hr}$.

The enzymes surveyed electrophoretically and abbreviations used are as follows: Glucose-6-phosphate dehydrogenase - G6PD (1.1.1.49); Hexose6-phosphate dehydrogenase - H6PD (1.1.1.47); Phosphoglucomutase - PGM (2.7.5.1); Xanthine dehydrogenase - XDH (1.1.1.25); Isocitrate dehydrogenase - IDH (1.1.1.42); Malate dehydrogenase - MDH (1.1.1.37); Malic enzyme - ME (1.1.1.40); Glutamate oxaloacetate transaminase - GOT $(2.6,1,1)$; Superoxide dismutase - SOD (1.15.1.1); Sorbitol dehydrogenase SDH $(1,1,1,14)$; Esterase - Est $(3,1,1,1)$; Lactate dehydrogenase - LDH $(1,1,1,27)$; Phosphoglucoisomerase - PGI (5.3.1.9); Adenylate kinase - A $(2,7.4 .3)$; Hexosekinase - Hk (2.7.1.1);Glucuronidase - GUS.

Results

The products of thirty-three loci from three populations of ThymaZlus arcticus have undergone preliminary electrophoretic screening (Table 2). In this initial screening no differences have been found between the Bighole River and Grebe Lake grayling. This result is similar to that of last year, but with new enzyme systems and a larger sample, differences may be found. Three new enzyme systems (Gus, AK and HK) have been added to the screening program, and more additions are planned. The sample size collected is larger than last year but all of the samples have not been included.

The Red Rock lakes population is a native population never subjected to transplanting. The samples were collected with the Montana Fish and Game in conjunction with egg collections. The G6PD isozyme from that population appears to be different from G6PD in Grebe Lake or Bighole River populations. This difference will have to be verified with additional buffers and a greater sample size. This appears to be the only difference to date.

\section{Conclusions}

From the preliminary results, we conclude that there may be a difference between Grebe Lake and Red Rock lakes populations. There is no evidence for any difference between Grebe Lake and the Bighole River populations. Analysis of other populations and increased sample sizes of these populations is required before any genetic comparisons can be made between lacustrine and adfluvial populations. 


\section{$\underline{\text { Literature } \text { Cited }}$}

Allendorf, F. W., F. M. Utter, and B. P. May. 1975. Gene Duplication within the family Salmonidae: 11 . Detection and determination of the genetic control of duplicate loci through inheritance studies and the examination of populations. pp. 415-432. In: Isozymes IV: Genetics and Evolution. Edited by C. L. Markert. Academic Press, New York.

Allendorf, F. W., N. Mitchell, N. Ryman and G. Stahl. 1977. Isozyme loci in Brown Trout (Salmo trutta L.): Detection and interpretation from population data. Hereditas 86: 179-190.

Lynch, J. C. and E. R. Vyse. 1979. Genetic variability and divergence in grayling, Thymallus areticus. Genetics: In Press.

Harris, H., and D. A. Hopkinson. 1976. Handbook of Enzyme Electrophoresis in Human Genetics. American Elsevier Pub. Co., N.Y.

Selander, R. K., M. H. Smith, S. Y. Yang, W. E. Johnson and J. B. Gentry. 1971. Biochemical polymorphism and systematics in the genus Peromyscus 1. Variation in the old fieldmouse(Peromyscus pelionatus). Studies of Genetics VI. Univ. of Texas Publ. No. 7103. pp. 49-90.

\section{Acknowledgments}

I wish to thank the Yellowstone National Park Fisheries staff particularly R. Jones and J. Varley for help with sample collection in YNP and to Montana Fish and Game for help in collecting Montana specimens. 
Table 1. Grayling population sampling, 1978.

\begin{tabular}{llc}
\hline Date & Source & \# Fish \\
\hline May 23 & Red Rock lake inlet, S. W. Montana & 20 \\
May 26 & $\begin{array}{c}\text { Mussigbrod Reservoir, Bighole River drainage, } \\
\text { Montana }\end{array}$ & 8 \\
June 22 & Grebe Lake and hatchery creek inlet (YNP) & 25 \\
July 10 & Deer Lake, Spanish Peaks, Montana & 10 \\
July 16 & Emerald Lake, Gallatin Range, Montana & 10 \\
Aug, 9 & Fuse Lake, Sapphire Mountains, Montana & 19 \\
Aug. $16-24$ & Lemarche Creek, Blghole River drainage, \\
Aug. 24 & Bighole River near Wisdom, Montana & 35 \\
\hline
\end{tabular}




$$
-145-
$$

Table 2. Number of Individuals Sampled.

\begin{tabular}{|c|c|c|c|}
\hline Loci & Grebe Lake (YNP) & Bighole River & Red Rock \\
\hline LDH-1-5 & 12 & & 12 \\
\hline $\mathrm{MDHs}-1 \varepsilon 2$ & 12 & & 12 \\
\hline $\mathrm{MDHm}$ & 12 & & 12 \\
\hline G6PDH- $1 \& 2$ & 12 & & 12 \\
\hline PGM I-3 & 12 & 12 & \\
\hline Est & 12 & & 12 \\
\hline SOD & 12 & & 12 \\
\hline MEm & 12 & 12 & \\
\hline MEs $-1 \& 2$ & 12 & 12 & \\
\hline H6PD & 12 & 12 & 12 \\
\hline SDH & 12 & 25 & 12 \\
\hline XDH & 12 & 12 & \\
\hline$P G I-1-3$ & 12 & 25 & 12 \\
\hline $\mathrm{IDH}$ & 12 & & 12 \\
\hline GOT $-1 \& 2$ & 12 & & 12 \\
\hline GUS & & 25 & \\
\hline Ak & 12 & 12 & \\
\hline $\mathrm{Hk}$ & 12 & & 12 \\
\hline
\end{tabular}

